\title{
Angeläget men rörigt i ny bok om judiskt liv i Stockholm
}

\author{
BoKreCENSION • BoOK REVIEW
}

DOI: https://doi.org/10.30752/nj.85031

Gravstenar berättar. Judiskt liv i Stockholm 1775-1875 [Stories of the Headstones: Jewish Life in Stockholm, 1775-1875], red. Yvonne Jacobsson, Gabriel Herdevall \& Petr Zupanc. Stockholmia Förlag 2018. 151 sidor.

Den tyske juden Aaron Isaac (I730-I8r6) var den första jude som tilläts att bosätta sig i Sverige utan att konvertera till kristendomen. Att han anlände 1774 är väl känt men det kanske är mindre känt att han två år senare grundade den första judiska begravningsplatsen i Sverige. Platsen döptes senare, efter honom, till Aronsberg och är belägen på Kungsholmen mellan Alströmergatan och Igeldammsgatan. Eftersom den judiska traditionen säger att begravningsplatser ska vara eviga finns den kvar på samma plats än idag där den fortfarande är möjlig att besöka.

Under åren 200I-20I6 genomförde Länsstyrelsen i Stockholm ett omfattande restaureringsarbete av gravstenarna vid Aronsberg och Kronoberg (grundad I787) och det är en av utgångspunkterna för boken Gravstenar berättar. Judiskt liv i Stockholm I775-I875 som utkom år 2018 på Stockholmia förlag.

Boken är en antologi som består av sju kapitel. Det första kapitlet är en kort inledning av den tidigare överrabbinen Morton

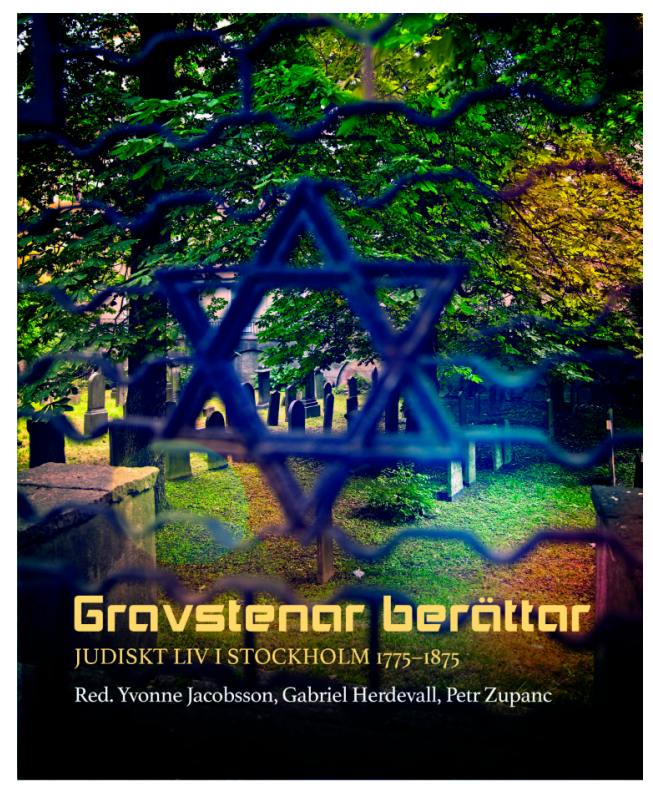

Narrowe. Det andra kapitlet är en prolog av arkitekten Gabriel Herdevall som tillsammans med arkitekten Petr Zupanc arbetade med restaureringen av gravstenarna. Det tredje kapitlet är skrivet av tidigare nämnda Zupanc och Herdevall tillsammans med kantorn Maynard Gerber och tidigare chefen för Judiska museet, Yvonne Jacobsson. Kapitlet handlar om begravningsplatserna Aronsberg och Kronoberg men också om det judiska begravningssällskapet Cherva Kadisha, som grundades I788 i Sverige. Uppgiften för 
Chevran är att vårda sjuka och sörja för de döende och de döda.

Kapitel fyra är skrivet av ekonomhistorikern Rita Bredefeldt och handlar om de första hundra åren av judisk invandring till Sverige. Bredefeldt beskriver den judiska minoriteten som en betydelsefull aktör i den svenska samhällsutvecklingen. Hon pekar på den judiska släkten Lamm som ett intressant exempel "eftersom många av dess medlemmar var typiska för tidens judiska företagare med deras uppgående sociala mobilitet" som kombinerade innovationer med entreprenörskap (s. 54). Samtidigt problematiseras beskrivningen av den judiska invandringen med det motstånd som fanns och som ofta grundades $i$ antisemitism. Under åren $1782-1838$ fanns det så kallade Judereglementet som begränsade var judar fick bosätta sig och vad de fick arbeta med. Reglementet gjorde att den judiska gruppen inte betraktades som svenska medborgare utan som tillhörande "den judiska nationen" (s. 69). Först år I870, samma år som den så kallade emancipationen i Europa, fick gruppen fullständiga politiska och medborgerliga rättigheter.

Det femte kapitlet handlar om gravstenarnas utformning - både text och stenens form - och är skrivet av arkitekten Petr Zupanc.

Det sjätte kapitlet är skrivet av historikern Carl Henrik Carlsson och handlar om några av de tidiga judarna som levde i Stockholm varav flera är begravda på Aronsberg och Kronoberg. Carlsson berättar kunnigt och intressant om Aaron Isaac, om hans efterträdare, de ingifta släktingarna Isaac Michaelsson (I754-I825) och Michael Bendicks (I768-I845), men också om "de osynliggjorda kvinnorna" (s. I2O). Han diskuterar det faktum att eftersom männen oftare deltog i offentligheten så lämnade de också oftare spår efter sig i källorna, men han pekar också på att det går att rekonstruera ganska stora delar av även kvinnornas liv genom andra källor än de offentliga, exempelvis brev, dagböcker och nedtecknade minnen. I kapitlet får vi därför lära oss att dottern Ester Isaac (ca I766-I79I) och hennes kusin Recha Abraham (I773-I839) blev bortgifta tidigt men att Esters protester - "jag är ju ännu ett barn och går i skolan" - ledde till att bröllopet sköts upp tills hon blev i6 år. Vi får också lära oss mer om den svenskjudiska släkten Josephson och särskilt Beata Josephson, född Levin (I79I-I859), vars begåvade ättlingar har fått artiklar efter sig i både Nationalencyclopedin och Svenskt biografiskt lexikon.

Det sjunde kapitlet är ett efterord av stadsantikvarien Ann-Charlotte Backlund. Boken avslutas med ordförklaringar och ett gravregister (som dock inte är fullständigt).

Antologin har ett angeläget ämne men är tyvärr lite rörig och otydlig. En sådan otydlighet rör bokens anslag och syfte. Det faktum att den har minst tre inledningar (kanske fyra om efterordet räknas in) som alla säger lite olika saker bidrar till otydligheten. I baksidestexten sägs syftet vara att "bidra till kunskap och insikt om hur denna tidiga invandring påverkat utvecklingen av Stockholm och Sverige" och ger alltså för handen att boken bidrar till invandringens historia. I Narrowes fina inledningstext finns en beskrivning av boken som en "värdefull komplettering av Frieds arbete" det vill säga skriften Gamla judiska gravplatser $i$ Stockholm som gavs ut I927 av religionsläraren Dr. Moses Fried, och här uttalas också en önskan om att inspirera "till att även idag använda enklare traditionella gravstensformer" (s. Io). Av detta uppkommer frågan om hur den nya boken förhåller sig till den tidigare boken från I927 och vad som egentligen är bokens fokus?

I prologen, som också används i bokens inflikstext, berättar arkitekten Herdevall om hur han och de andra som arbetade med restaureringen av gravstenarna blev imponerade av de gamla inskriptionerna och vilken historia de berättar (s. I2) medan arkitekten Zupanc 
skriver att"det är denna boks syfte att fördjupa och sammanställa historien från denna tid, från de första hundra åren av judiskt liv" (s. I4). Av dessa ord och av bokens titel tror man därför att fokus ligger på själva restaureringen. Slutligen finns i stadsarkivarien Backlunds efterord beskrivningen att länsstyrelsernas intresse handlar om begravningsplatsernas kulturhistoriska värde i stadsbilden eftersom det är ovanligt med "spår i stadsbilden från våra nationella minoriteter" (s. I44). Av efterordet verkar boken alltså vilja vara ett bidrag till minoriteternas historia.

Alla dessa olika syften och önskemål är i sig vällovliga och intressanta, men jag som läsare önskar att bokens redaktörer hade bestämt sig för vad det var för bok de ville ge ut, och låtit det få konsekvenser för urvalet av artiklar. Möjligen ligger en del av förklaringen till det försiktiga redigerandet i att en redaktörerna, Petr Zupanc, dog innan boken hann färdigställas. Redaktörerna borde också ha lämnat de historiska beskrivningarna och tolkningarna till forskarna. Som det är nu finns det påståenden som inte beläggs och i något fall går på tvärs med forskningen. Det senare gäller beskrivningen av relationen mellan majoritetssamhället och den judiska gruppen i Sverige som av "jämförelsevis fridsamma karaktär" (s. I4). Det är en slutsats som förvånar en medredaktör till antologin En problematisk relation? Flyktingpolitik och judiska fyktingar i Sverige I920-1950 ${ }^{\mathrm{I}}$ och som också går på tvärs med vad som sägs i Bredefeldts kapitel. Dessutom finns delar som ligger väldigt nära den första

1 Länk till e-resurs: <http://libris.kb.se/ bib/14604295>. boken av Fried, men som inte citeras, vilket ger ett ovetenskapligt intryck. Det är synd men kan förmodligen förklaras av en okunskap om hur man skriver vetenskaplig text. Utöver det upprepas vissa påståenden väl många gånger, exempelvis berättelsen om Aaron Isaac, vilket ger intryck av att boken inte är redigerad till en helhet.

Det är som sagt synd för det kryllar inte precis av den här typen av böcker i Sverige. För den som är intresserad av judisk historia skulle jag ändå rekommendera att läsa den här boken tillsammans med boken Gamla judiska gravplatser $i$ Stockholm som finns att ladda ner som pdf från Adat Jeschuruns webbplats. ${ }^{2}$

KARIN KVIST GEVERTS

Karin Kvist Geverts, fil.dr. i historia. Disputerade 2008 på avhandlingen Ett främmande element i nationen. Svensk flyktingpolitik och de judiska flyktingarna 19381944 (<http://libris.kb.se/bib/17001489>) vid Hugo Valentin-centrum vid Uppsala universitet. Hennes senaste publikationer är "Tracing the Holocaust in early writings in post-war Sweden" i The Early Holocaust Memory in Sweden. Archives, Testimonies and Reflections, eds. Johannes Heumann och Pontus Rudberg (London, Palgrave, 2019; kommande) och "Antisemitism in Sweden: a neglected field of research?" i Antisemitism in the North, eds. Cordelia Heß och Jonathan Adams (Berlin, DeGruyter, 2019 <https:// www.degruyter.com/downloadpdf/ books/9783110634822/9783110634822 012/9783110634822-012.pdf>).

2 Länk till e-resurs: <http://www.jeschurun.se/gravplatser.php)>. 